\title{
Shrub richness is primarily driven by climate conditions in Southwestern European woodlands
}

\author{
Daniel Moreno-Fernández ${ }^{1}\left(\mathbb{D} \cdot\right.$ Isabel Cañellas $^{2} \mathbb{D} \cdot$ Iciar Alberdi $^{2} \mathbb{B}$
}

Received: 17 May 2021 / Accepted: 22 November 2021 / Published online: 2 December 2021

(c) The Author(s) 2021

\begin{abstract}
- Key message The shrub species richness in Spanish forests is mainly linked to climatic variables and the importance of the groups of variables scarcely differs among forest types. Forest surrounding the Mediterranean Basin exhibit the highest levels of shrub richness.

- Context Shrub species account for a high proportion of the plant diversity in Spanish forests and are a determinant factor in forest dynamics and ecosystem functionality.

- Aims To investigate the relative importance of climatic, forest stand features, soil and topographic variables in explaining shrub richness in Spanish forests and if the relative importance of these four groups of variables reflects variations among forest types.

- Methods We used the Spanish National Forest Inventory and a boosted regression trees approach to identify which climatic, soil, stand and topographic variables ( $N=19$ variables) are related to the richness of shrub species in Spanish woodlands.

- Results The shrub species richness is mainly related to climatic variables followed by soil variables whereas stand and topographic variables play a minor role. The importance of the groups of variables scarcely differs among forest types although forests located around the Mediterranean Sea display the highest levels of shrub richness.

- Conclusion Shrub richness in Spain is primarily driven by climatic and soil variables, both at country and forest-type scales. Forests surrounding the Mediterranean Basin account for the highest richness of shrub species but are also those most threatened by global change. Therefore, special attention must be paid to the monitoring and assessment of these forest ecosystems.
\end{abstract}

Keywords Adaptive management $\cdot$ Habitat indicators $\cdot$ Sustainability $\cdot$ Plant diversity

\section{Introduction}

The Mediterranean basin is considered a hotspot of diversity as it harbors many endemic species (Myers et al. 2000; Hewitt 2011; Molina-Venegas et al. 2017; Di Pasquale et al. 2020). As in other hotspots, the native species of the Medi-

Handling Editor: Laurent Bergès

Daniel Moreno-Fernández

danielmorenofdez@gmail.com

Iciar Alberdi

alberdi@inia.es

1 Departamento de Ciencias de la Vida, Forest Ecology and Restoration Group, Edificio Ciencias, Universidad de Alcalá, Campus Universitario, 28871 Alcalá de Henares, Madrid, Spain

2 INIA-CIFOR, Ctra. A Coruña km 7.5, E-28040 Madrid, Spain terranean basin are threatened by global change, although these countries are wealthier and can contribute with more resources behind environmental conservation alleviating the impact of global change on biodiversity (Habel et al. 2019). Therefore, it would seem appropriate to implement and develop programs for monitoring and conservation of biodiversity as well as to identify those factors driving species occurrence and potential threats (Molina-Venegas et al. 2017; Chandler et al. 2017).

Shrub layer is an important component in the provision of different services and functions in forest ecosystems, 
such as food and refugia for many organisms (Focardi and Tinelli 2005; Gastón et al. 2019), pollination (Rodríguez and Kouki 2015), fruits and berries for human and animal consumption (Miina et al. 2016), restoration of damaged environments (Torroba-Balmori et al. 2015; Alday et al. 2016; López-Marcos et al. 2020), the reduction of run-off (Mohammad and Adam 2010), reversal of desertification (Maestre et al. 2009), carbon storage (Pasalodos-Tato et al. 2015) or provision of bioenergy (González-González et al. 2017).

Additionally, shrubs have an important role in the natural forest dynamics, especially during the first stages of tree development. With this regard, several studies have highlighted the importance of shrub presence on the establishment and development of new seedlings in areas with intense, severe drought (Smit et al. 2008; Moreno-Fernández et al. 2019), but also under milder climatic conditions where water stress intensifies from the lack of soil structure (Torroba-Balmori et al. 2015; Alday et al. 2016), although the relationship between shrubs and trees seems to be speciesspecific (Gómez-Aparicio et al. 2004; Madrigal-González et al. 2014; Cruz-Alonso et al. 2020). Under such conditions, shrubs provide shade and protection for seedlings against browsing damage caused by domestic and wild ungulates. The protection of seedlings by shrubs against browsing has also been reported in temperate forests (Jensen et al. 2012). Shrub clearance, however, has long been common practice in Mediterranean areas to reduce competition with trees, to facilitate forest operations, increase the agricultural area, improve grassland for cattle, and mitigate fire risk by reducing fuel load and breaking the vertical continuity of the fuel (Pérez-Ramos et al. 2008; Lasanta et al. 2018). Moreover, under the current context of global warming, the shrub stratum gains importance as shrubs depict more tolerance to drought and aridity than tree species (Liu et al. 2011; Bateman et al. 2018) and can be one of the last barriers against desertification and soil erosion in water-limited environments (Maestre et al. 2009).

Given the importance of shrub species in forest processes and functions (López-Marcos et al. 2019), it is of great interest to identify and describe the composition and dynamics of shrub communities along environmental gradients, as well as to identify the response of shrub species to environmental conditions (Olthoff et al. 2016, 2021; Bhatta et al. 2018; Jordan et al. 2020; Das Gupta and Pinno 2020). Due to the importance of the shrub stratum, the assessment of habitats included in the Natura 2000 Network considers the shrub composition as well as its maintenance across different ecosystems (Cantarello and Newton 2008; Silva et al. 2019, 2020). In fact, Member States are obliged by Article 11 of the Habitats Directive to undertake surveys and inventories which should provide the basis for assessment, the shrub strata being a key component.
Spain is an important country with regard to the study of plant diversity because apart from being located within a biodiversity hotspot, it contains four biogeographical regions -Atlantic, Alpine, Mediterranean and Macaronesian (see sections below for further description). These biogeographical regions are, in turn, divided into several subclimates, mainly because of the altitudinal ranges that give rise to different forest types. Most of the studies addressing shrub species richness in forests around the Mediterranean basin hotspot have focused on a single biogeographical region (Gracia et al. 2007; Torras et al. 2008; Martín-Queller et al. 2011; Zilliox and Gosselin 2014) or the transition between two regions (Olthoff et al. 2016, 2018, 2021). However, the relationships among forest-related variables as well as forest processes may vary when modifying the study scale and data source (Olthoff et al. 2018; Vicente-Serrano et al. 2020). In this line, Moreno-Fernández et al. (2020) linked shrub richness to stand variables in monospecific forests of the main tree species but did not consider environmental variables such as climatic, soil or topography. In this regard, shrub species and the relationships between environmental/stand predictors and understory species richness can reveal variations among forest types (Härdtle et al. 2003; Duan et al. 2019; López-Marcos et al. 2019). However, as far as we know, no study to date has addressed shrub richness for the whole Spain and the variables driving this ecological pattern using an explicit spatial analysis.

The main aim of this study is to analyse the spatial patterns of shrub richness and to identify the climatic, forest stand features, soil and topographic variables related to shrub species richness in Spanish woodlands. We aim to answer the following research questions: What is the relative importance of climatic, forest demographic, soil and topographic variables in explaining shrub richness in Spanish forests? Does the relative importance of these four groups of variables reflect variations among forests types?

\section{Material and methods}

\subsection{Dataset}

In this study we use the Third Spanish National Forest Inventory (NFI), which was carried out between 1997 and 2007. The NFI consists of permanent plots established in forest areas (coverage of tree species greater than or equal to 10 $\%$ ) on a $1 \times 1 \mathrm{~km}$ grid. The plots follow a nested design with four concentric subplots of 5, 10, 15 and $25 \mathrm{~m}$ radii in which adult trees are measured according to a minimum diameter at breast height (dbh) threshold (7.5, 12.5, 22.5 and $42.5 \mathrm{~cm}$, respectively) (Alberdi et al. 2016; Olthoff et al. 2016, 2018).

As in most NFIs (Alberdi et al. 2010), the Spanish NFI identifies the most common and relevant shrub species (or 
taxa) within the 10-m-radius subplot (219 of which there are 169 species, 48 genus, and 2 subfamily subgroups). The shrub species list was elaborated taking into consideration both floristic aspects (such as dominance, distribution area), ecological aspects (such as species bioindicators or naturalness) as well as other factors of interest (such as biomass, wildfires or livestock browsing). Technical limitations, ubiquity, shrub conservation status or invasiveness have also been considered. It is worth noting that, in general, the individual shrubs are identified at species level but when species identification is not possible, only the genus is recorded. The Spanish NFI considers shrubs such as woody perennial plants, generally less than 5 meters in height at maturity and without a definite crown. However, for practical reasons, vigorous herbaceous climbing plants are also included in this list, so they can be recorded. For each NFI plot, we calculated the shrub richness as the sum of all shrub records within the 10 -m-radius subplot. We refer to each shrub record gathered in the NFI plots as shrub species regardless of the taxa (genus or species). Appendix 2 Table 5 contains the list of shrub species considered in the Third NFI. Climbing species included in the shrub species list of the NFI, such as Hereda helix L., were not considered in this study. For the purposes of this study, we considered plots with the presence of at least one adult tree $(\mathrm{dbh} \geq 7.5$ $\mathrm{cm}$ ) to eliminate the gap between 0 and $7.4 \mathrm{~cm}$ (plots without adult trees but with presence of seedlings and/saplings) in the mean plot dbh, obtaining a continuous variable.

Spain contains four biogeographical regions (Roekaerts 2002). The Atlantic region is located in Northern Spain, in areas subjected to the influence of the Atlantic Ocean. The Alpine region is that within and surrounded by the Pyrenees while the Macaronesian region corresponds to the Canary Islands. Finally, the Mediterranean region accounts for most of the area of the country. Due to the large extent of this region there is intra-variability of climate conditions, ranging from arid conditions in southern locations to subalpine and oro-mediterranean conditions in some of the Mediterranean montane systems.

Appendix 2 Table 5 presents the location of the four biogeographical regions as well as maps for mean annual temperature and mean cumulative rainfall derived from WorldClim2 (Fick and Hijmans 2017). The dataset comprised 81,017 plots of which $4.1 \%$ were located in the Alpine, $17.9 \%$ in the Atlantic, $3.0 \%$ in the Macaronesian and 75.0 $\%$ in the Mediterranean biogeographical region (Table 1).

We assigned forest type to each plot according to the Spanish National Forest Map (MITECO 2013). However, this map considers a very large number of types (ca. 70), so to facilitate the interpretation and identification of gradients by forest type we merged them into the following 10 broader spectrum forest types: Subalpine and oro-mediterranean conifers, Mediterranean conifers, Macaronesian
Table 1 Number of plots (N plots), mean shrub species (standard deviation in brackets), and the total number of shrub species ( $\mathrm{N}$ shrub) by biogeographical region

\begin{tabular}{llll}
\hline Biogeographical region & N plots & Mean shrub species & N shrub \\
\hline Alpine & 3348 & $2.44(1.75)$ & 100 \\
Atlantic & 14420 & $3.01(1.92)$ & 103 \\
Macaronesia & 2449 & $1.40(1.25)$ & 50 \\
Mediterranean & 60800 & $4.29(3.13)$ & 185 \\
Total & 81017 & $3.90(3.00)$ & 195 \\
\hline
\end{tabular}

conifers, Deciduous broadleaves, Evergreen broadleaves, Mixed stands of conifers and broadleaves, Open woodlands, Productive plantations and Unclassified plots.

For each biogeographical region and forest type, we calculated the mean number of shrub species per plot.

\subsection{Candidate variables to explain the shrub richness in Spain}

We considered the following climatic, stand, soil and topographic variables as drivers of shrub richness in Spain (Table 2):

* Climatic variables derived from WorldClim2 (Fick and Hijmans 2017), which is available at https://www.world clim.org: i) mean annual temperature (Temp, $\left.{ }^{\circ} \mathrm{C}\right)$, ii) mean cumulative rainfall (Rainfall, $\mathrm{mm}$ ), iii) and iv) temperature and rainfall variability as the ratio of the standard deviation of monthly values and the mean, this is the coefficient of variation (Var_Temp and Var_Rainfall, respectively, adimensional).

* Stand variables calculated from the NFI: v) plot basal area $\left(\mathrm{BA}, \mathrm{m}^{2} \mathrm{ha}^{-1}\right)$, vi) mean plot dbh (DBH, cm), vii) the number of adult trees per ha $(\mathrm{N})$.

* Soil variables of the uppermost $5 \mathrm{~cm}$ of the soil extracted from SoilGrids2 (https://soilgrids.org/)(Poggio et al. 2021): viii) bulk density ( $\left.\mathrm{cg} \mathrm{cm}^{-3}\right)$, ix) sand $\left(\mathrm{g} \mathrm{kg}^{-1}\right)$, $\mathrm{x})$ silt $\left(\mathrm{g} \mathrm{kg}^{-1}\right)$, xi) clay $\left(\mathrm{g} \mathrm{kg}^{-1}\right)$, xii) coarse fragments $\left(\mathrm{cm}^{3}\right.$ $\left.\mathrm{dm}^{-3}\right)$, xiii) cation exchange capacity at ph 7 (CEC, mmol(c) $\left.\mathrm{kg}^{-1}\right)$, xiv) organic carbon $\left.\left(\mathrm{OC}, \mathrm{dg} \mathrm{kg}^{-1}\right), \mathrm{xv}\right) \mathrm{pH}$ in $\mathrm{H} 2 \mathrm{O}$, $\mathrm{xvi}$ ) nitrogen $\left(\mathrm{cg} \mathrm{kg}^{-1}\right)$.

* Topographic variables derived from from WorldClim2: xvii) slope $\left({ }^{\circ}\right)$, xviii) aspect $\left({ }^{\circ}\right)$, xix) altitude $(\mathrm{m})$.

\subsection{Boosted regression trees}

We used boosted regression trees (hereafter, BRT) to relate the number of shrub species (Nshrub) in the $i$-th plot $(i=$ $1, \ldots, 81,017$ ) to the 19 predictors described above (see Table 3 for the mean values and dispersion statistics). BRT is a machine learning method that combines many trees and can be thought of as a regression model in which each term 
Table 2 Maximum, mean and minimum values of the climatic, stand, soil and topographic variables considered to fit the boosted regression trees model
Table 3 Number of plots (N plots), the mean number of shrub species (standard deviation in brackets) and the the total number of shrub species ( $\mathrm{N}$ shrub) by forest type

\begin{tabular}{|c|c|c|c|c|}
\hline Variable & & Minimum & Mean & Maximum \\
\hline \multicolumn{5}{|c|}{ Climatic variables } \\
\hline & Rainfall (mm) & 177.0 & 707.2 & 1988.0 \\
\hline & Temperature $\left({ }^{\circ} \mathrm{C}\right)$ & 1.8 & 12.3 & 19.8 \\
\hline & Var_Temp & 0.1 & 0.5 & 2.7 \\
\hline & Var_Rainfall & 0.1 & 0.4 & 0.9 \\
\hline \multicolumn{5}{|c|}{ Stand variables } \\
\hline & Basal area $\left(\mathrm{m}^{2} \mathrm{ha}^{-1}\right)$ & 0.4 & 14.0 & 79.7 \\
\hline & Plot DBH (cm) & 7.5 & 22.0 & 158.8 \\
\hline & $\mathrm{N}\left(\#\right.$ trees $\left._{\mathrm{ha}} \mathrm{a}^{-1}\right)$ & 5 & 502 & 5889 \\
\hline \multicolumn{5}{|c|}{ Soil variables } \\
\hline & Bulk density $\left(\mathrm{cg} \mathrm{cm}^{-3}\right)$ & 86.0 & 119.1 & 150.0 \\
\hline & Sand $\left(\mathrm{g} \mathrm{kg}^{-1}\right)$ & 124.0 & 388.7 & 712.0 \\
\hline & Silt $\left(\mathrm{g} \mathrm{kg}^{-1}\right)$ & 129.0 & 383.2 & 676.0 \\
\hline & Clay $\left(\mathrm{g} \mathrm{kg}^{-1}\right)$ & 81.0 & 228.1 & 427.0 \\
\hline & Coarse fragments $\left(\mathrm{cm}^{3} \mathrm{dm}^{-3}\right)$ & 64.0 & 170.8 & 336.0 \\
\hline & $\mathrm{CEC}\left(\mathrm{mmol}(\mathrm{c}) \mathrm{kg}^{-1}\right)$ & 148.0 & 259.8 & 517.0 \\
\hline & Organic carbon $\left(\mathrm{dg} \mathrm{kg}^{-1}\right)$ & 160.0 & 677.2 & 1727.0 \\
\hline & $\mathrm{pH}$ & 4.5 & 6.5 & 8.2 \\
\hline & Nitrogen $\left(\mathrm{cg} \mathrm{kg}^{-1}\right)$ & 158.0 & 514.1 & 1254.0 \\
\hline \multicolumn{5}{|c|}{ Topographic variables } \\
\hline & Slope $\left(^{\circ}\right)$ & 0.0 & 4.2 & 30.3 \\
\hline & Aspect $\left({ }^{\circ}\right)$ & 0.0 & 181.6 & 360.0 \\
\hline & Altitude (m) & 0.0 & 792.6 & 2657.0 \\
\hline
\end{tabular}

Rainfall $=$ mean cumulative rainfall; Temp $=$ mean annual temperature; Var_Temp and Var_Rainfall $=$ temperature and rainfall variability as the ratio of the standard deviation of monthly values and the mean, respectively; $\mathrm{DBH}=$ mean plot dbh; $\mathrm{N}=$ number of trees per ha; $\mathrm{CEC}=$ cation exchange capacity at ph 7

\begin{tabular}{llll}
\hline Forest type & N plots & Mean shrub species & N shrub \\
\hline Deciduous broadleaves & 7453 & $2.89(2.21)$ & 131 \\
Evergreen broadleaves & 13703 & $(4.3(2.84)$ & 161 \\
Macaronesian broadleaves & 402 & $1.92(2.20)$ & 61 \\
Macaronesian conifers & 1717 & $1.35(1.18)$ & 44 \\
Mediterranean conifers & 18072 & $5.13(3.30)$ & 157 \\
Mixed stands of conifers and broadleaves & 5759 & $4.62(3.16)$ & 146 \\
Open woodlands & 4930 & $1.98(2.30)$ & 114 \\
Productive plantations & 4972 & $3.36(2.19)$ & 118 \\
Subalpine and montane conifers & 12129 & $3.36(2.27)$ & 137 \\
Unclassified & 11896 & $3.83(3.07)$ & 158 \\
\hline
\end{tabular}

is a tree (Elith et al. 2008). In contrast to other machine learning techniques, such as random forests or bagging, BRT is based on boosting (De'ath 2007). Thus, for each new tree, the focus is on reducing the variation in the response that cannot be explained by previous trees (refer to Elith et al. (2008) for more details). BRT has several advantages over traditional approaches: no data transformation or elimination of outliers is required, it is relatively insensitive to the effects of multicollinearity, and complex nonlinear relationships and interactions among variables can be described (Schmidt and Drake 2011; Dedman et al. 2017).

Parameterizing a BRT model requires the tuning of learning rate (the contribution of each tree added in the model), tree complexity (number of nodes in each tree), and bag fraction (percentage of the data used to fit the model at each step) (Elith et al. 2008; Soykan et al. 2014). The first two parameters determine the number of trees in the model. In this work, we used a learning rate of 0.01 , a tree complexity 
of 4 and a bag fraction of 0.6 . The number of trees was set when the predictive deviance reached the minimum value for a given learning rate to reduce the overfitting. These values of learning rate and bag fraction ensured that the BRT was fitted with more than 1000 trees (Elith et al. 2008). We selected a Poisson structure of errors because the response variable (Nshrub) is count data.

The relative importance of predictors was calculated to estimate the influence of the four major groups of variables on shrub richness (Friedman 2001). Finally, we estimated the percentage of the deviance explained by the BRTs as follows:

Deviance explained $(\%)=\frac{(M T D-R D)}{M T D}$

where MTD is the mean total deviance and RD is the residual deviance. We fitted one BRT for the entire data set and one BRT for each of the above defined forest types. We carried out the BRT analyses using the "dismo" package in R 4.0.5 environment ( $\mathrm{R}$ Core Team 2021).

\section{Results}

\subsection{Spatial patterns of shrub species in south-western European forests}

Around $88 \%$ of the plots contained at least one shrub species. Similar values were found when analyzing the data by biogeographical region, except for the Macaronesian region, where the percentage of plots with shrub species dropped to $75 \%$. The ten species or genera with the greatest presence were Thymus spp. (present in 24,147 plots, i.e., $29.8 \%$ of the plots), Rosa spp. (15,369, $19.0 \%)$, Rubus spp. (15,352, 18.9 $\%)$, Salvia rosmarinus (L.) Schleid (14,471, $17.9 \%)$, Ulex spp. (13,329, $16.5 \%)$, Quercus coccifera L. $(9,756,12.0 \%)$, Erica arborea L. (8,005, $9.9 \%)$, Genista spp. (7,840, $9.7 \%)$, Pistacia lentiscus L. (7,773, $9.6 \%)$ and Cistus ladanifer L. $(7,132,8.8 \%)$.

We found that the plots with the largest number of shrub species were mainly located in the Mediterranean bioregion (mean $=4.29$ species per plot) followed by the Atlantic (3.00), Alpine (2.44) and Macaronesian (1.40) bioregions (Table 1). In Fig. 1 it can be seen that several shrub richness hotspots exist in forests close to the Mediterranean Sea and in southern Spain.

Mediterranean conifers followed by Mixed stands of conifers and broadleaves and by Evergreen broadleaves emerged as the forest types with the highest richness of shrub species (richness above 4 species per plot), whereas the two Macaronesian types (broadleaves and conifers) and the Open woodlands display the lowest number of shrub species per plot,

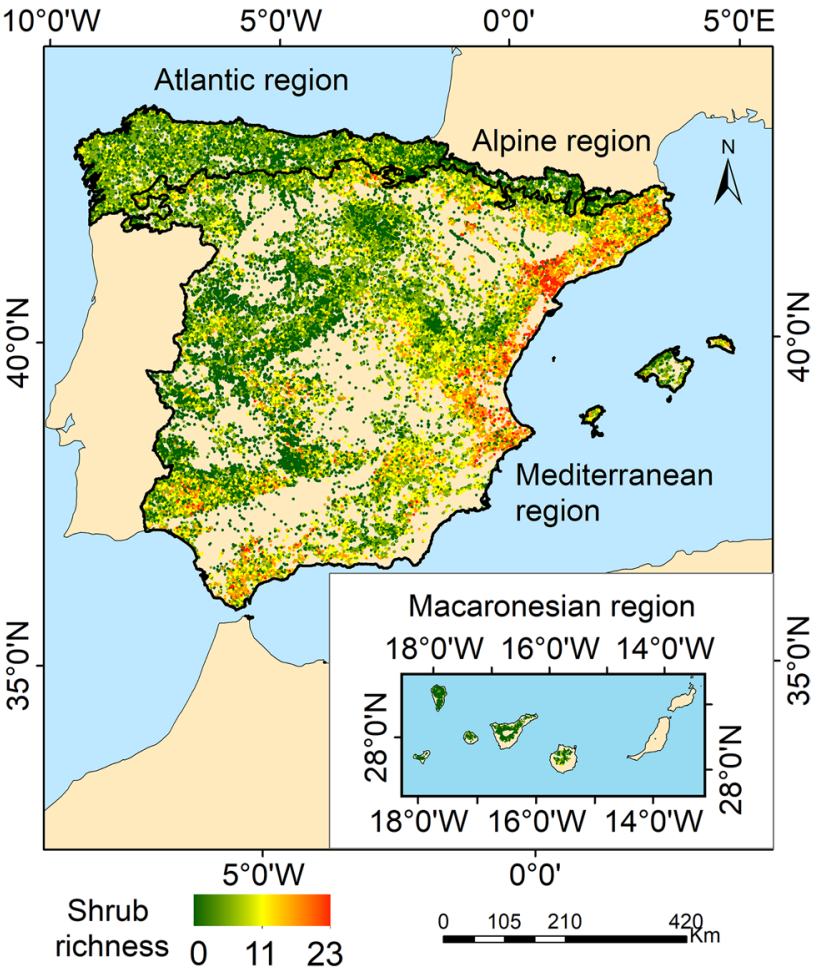

Fig. 1 Shrub richness in the NFI plots and the biogeographical regions

with mean values below 2. Finally, the forest types of the Atlantic, Alpine and the highest Mediterranean mountains (Deciduous broadleaves, Subalpine and oro-mediterranean conifers and Productive plantations) presented intermediate values of shrub richness with values around 3 (Table 3 ).

\subsection{Variables driving shrub species occurrence in Spanish forests}

The final BRT was fitted with 8100 trees and explained 38 $\%$ of the deviance (Table 4). Overall, climatic variables, followed by soil variables, were found to have the greatest influence on shrub richness. The variability of the rainfall (Var_Rainfall, relative importance $=15 \%)$, Temperature $(12$ $\%)$ and Altitude (12\%) emerged as the variables with the greatest influence on shrub richness while the soil bulk density, coarse fragments, aspect, tree density and clay content only contributed marginally to the BRT model (less than 2 \%) (Fig. 2).

The partial plot of the centered fitted function for rainfall variability presented two maxima (Fig. 3), the first one ranged from 0.2 to 0.4 and the second peaked around 0.7 . These two peaks coincide spatially with areas of high shrub richness. The highest values for rainfall variability (around 0.7) occur in the South of Spain whereas eastern Spain presented values of between 0.2 and 0.4 (Fig. 5 in Appendix 1). 
Table 4 Variance importance of the climatic, stand, soil and topographic variables as well as the total, residual and percentage of the deviance explained by the boosted regression trees by forest type. In bold, the group of variables with the greatest variance importance

\begin{tabular}{|c|c|c|c|c|c|c|c|}
\hline \multirow[b]{2}{*}{ Forest type } & \multicolumn{4}{|c|}{ Variable importance } & \multicolumn{3}{|c|}{ Deviance } \\
\hline & Climatic & Stand & Soil & Topographic & Total & Residual & Explained (\%) \\
\hline Whole data set & 40 & 13 & 30 & 17 & 2.41 & 1.49 & 38 \\
\hline Subalpine and oromediterranean conifers & 52 & 13 & 21 & 13 & 1.73 & 1.12 & 35 \\
\hline Mediterranean conifers & 51 & 6 & 24 & 19 & 2.38 & 1.50 & 37 \\
\hline Macaronesian conifers & 35 & 19 & 28 & 19 & 1.16 & 0.70 & 40 \\
\hline Deciduous broadleaves & 36 & 21 & 31 & 12 & 1.87 & 1.16 & 38 \\
\hline Evergreen broadleaves & 38 & 10 & 33 & 19 & 2.01 & 1.26 & 37 \\
\hline Macaronesian broadleaves & 49 & 14 & 25 & 12 & 2.26 & 1.00 & 56 \\
\hline Mixed stands of conifers and broadleaves & 32 & 10 & 34 & 24 & 2.30 & 1.22 & 47 \\
\hline Open woodlands & 28 & 22 & 36 & 13 & 2.60 & 1.43 & 45 \\
\hline Productive plantations & 38 & 14 & 37 & 12 & 1.69 & 1.12 & 34 \\
\hline Unclassified & 36 & 12 & 35 & 17 & 2.63 & 1.66 & 37 \\
\hline
\end{tabular}

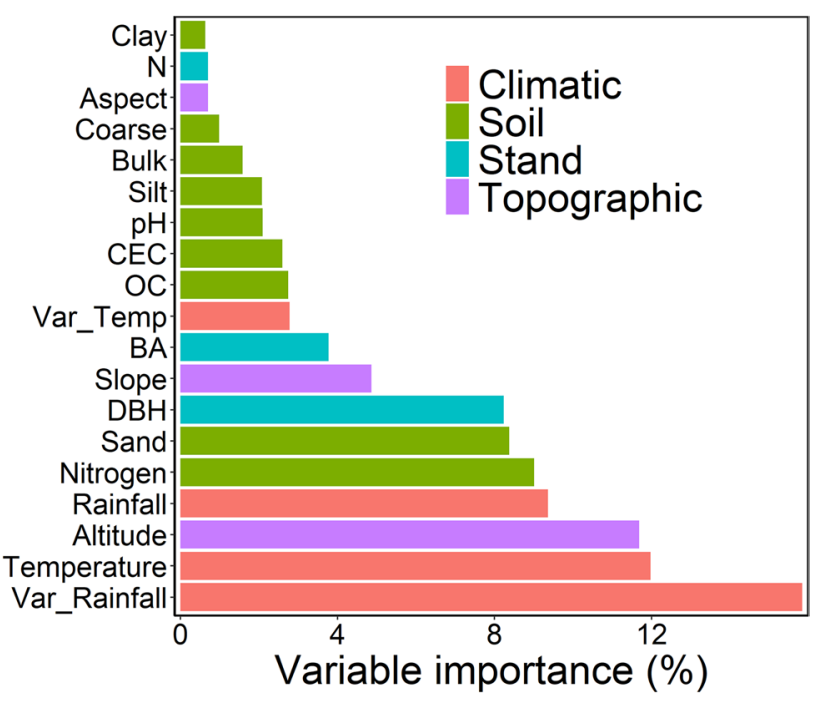

Fig. 2 Rainfall = mean cumulative rainfall; Temp = mean annual temperature; Var_Temp and Var_Rainfall = temperature and rainfall variability as the ratio of the standard deviation of monthly values and the mean, respectively; $\mathrm{DBH}=$ mean plot $\mathrm{dbh} ; \mathrm{N}=$ number of trees per ha; $\mathrm{CEC}=$ cation exchange capacity at $\mathrm{ph} 7$

The fitted function for Temperature reached a maximum at $13-17^{\circ} \mathrm{C}$, i.e., shrub richness increased at warmer locations. The warmest Spanish areas tend to correspond to the SouthWest and those near the East coast of the Iberian Peninsula as well as in the Balearic Islands (Mediterranean region) and the Canary Islands (Macaronesian region) (Fig. 6 in Appendix 1). Similarly, altitude was negatively related to shrub richness (see Fig. 7 in Appendix 1 for a digital elevation model of the study area). As regards the relationship between rainfall and shrub richness, the fitted function for this variable suggests that shrub richness tended to reach a maximum in forest growing in sites with moderate-low rainfall, around $600-700 \mathrm{~mm}$ per year. The highest levels of rainfall mainly occur in northern Spain (Atlantic and Alpine biogeographical regions) and, to a lesser extent, in some mountain ranges of the Mediterranean region (Fig. 8 in Appendix 1). These forests present low shrub richness values (Fig. 1). The number of shrub species also reached a maximum at moderate-low values of nitrogen $\left(300 \mathrm{cg} \mathrm{kg}^{-1}\right)$ and sand (200-300 $\left.\mathrm{g} \mathrm{kg}^{-1}\right)$. Nitrogen follows a N-S pattern (high values in the North and low in the South) (Fig. 9 in Appendix 1), which partially overlaps the pattern for shrub richness (Fig. 1). The regions with the highest of shrub species values are located in areas with low or moderate sand content (Fig. 1 and Fig. 10 in Appendix 1). However, it should be noted that the relative importance of sand is lower than that of the previously-mentioned variables. Finally, shrub richness decreased at higher plot DBH, i.e., shrub richness maximized in young stands.

The interactions between Rainfall variability and Temperature, and Rainfall variability with Rainfall, emerged as the two main interactions (Appendix 3 Table 6). The analysis of these two interactions reveals that shrub richness reached a maximum in forests located in warm and dry sites with low rainfall variability (Fig. 4), which is supported by findings from visual exploration (Fig. 1) and analyses of individual effects, i.e., partial plots (Fig. 3).

\subsection{Importance of groups of variables by forest type}

As regards the BRT by forest type, we found that overall, the climatic variables group explained the most variance for all the forest types followed by the soil variables, except for Mixed stands of conifers and broadleaves and Open woodlands. In these latter two forest types this order was reversed, although the variance explained by soil and 


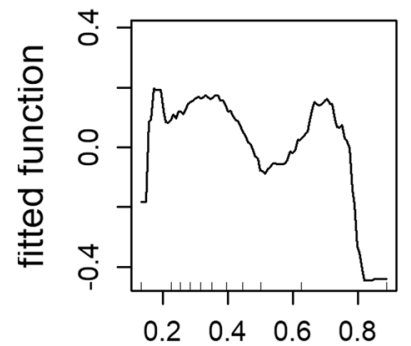

Var_Rainfall $(15.8 \%)$

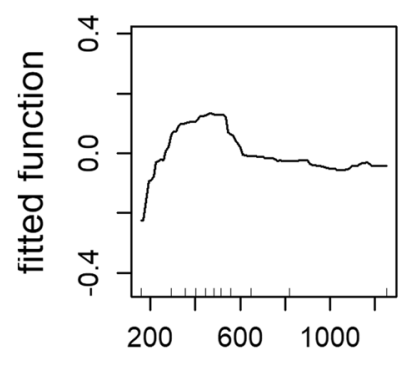

Nitrogen $(8.9 \%)$
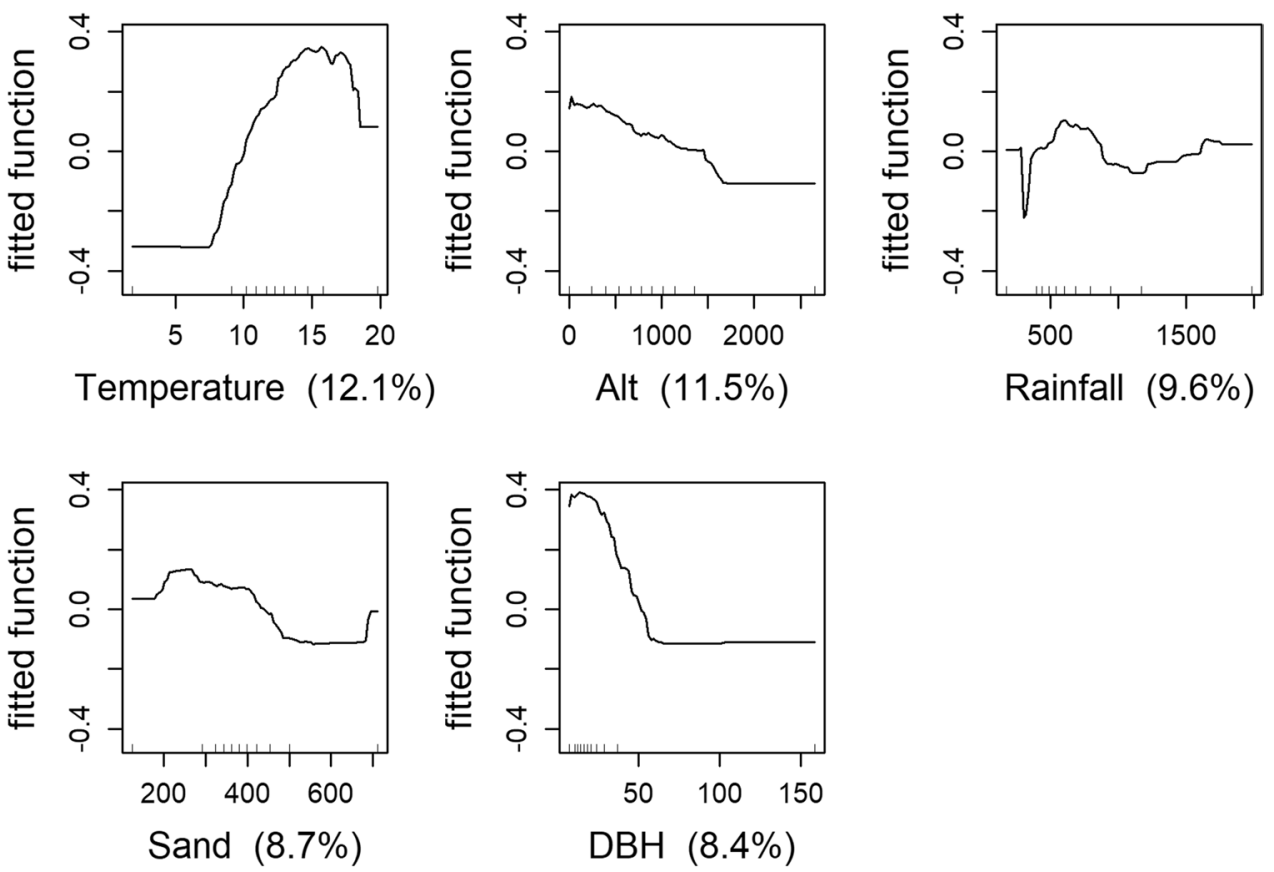

annual temperature $\left({ }^{\circ} \mathrm{C}\right)$; Alt $=$ altitude $(\mathrm{m}$ asl $)$; Rainfall $=$ mean cumulative rainfall $(\mathrm{mm})$; Nitrogen $(\mathrm{cg} / \mathrm{kg})$; Sand $(\mathrm{g} / \mathrm{kg}) ; \mathrm{DBH}=$ mean plot dbh $(\mathrm{cm})$

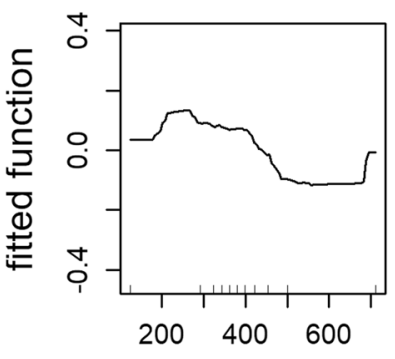

Sand $(8.7 \%)$
Fig. 3 Partial plots of the centered fitted functions for the predictors with the greatest relative importance of the boosted regression trees for the data as a whole. In brackets, the relative importance of each variable. Var_Rainfall $=$ rainfall variability; Temperature $=$ mean
Fig. 4 Three-dimensional partial dependence plots for the two strongest interactions in the boosted regression trees model
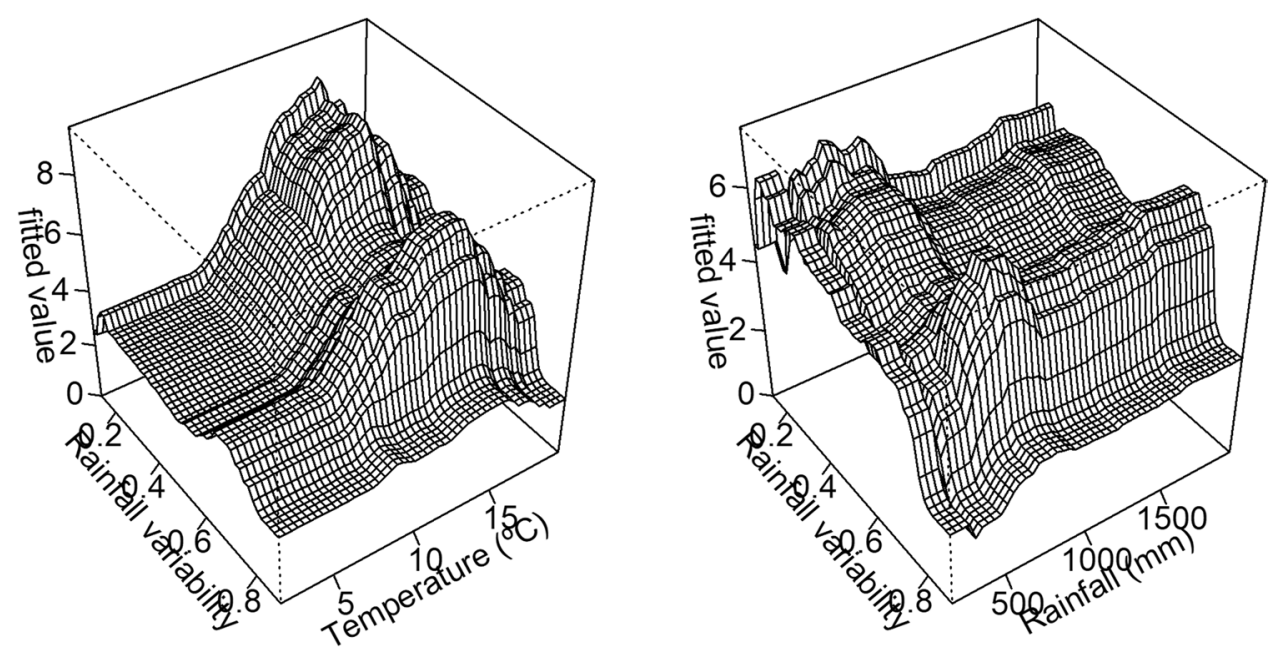

climatic variables was similar, especially for Mixed stands of conifers and broadleaves (Table 4). Moreover, the variance explained by climatic variables peaked for Subalpine and oromediterranean conifers, Mediterranean conifers and Macaronesian broadleaves at values of around 50. All the BRT models were fitted with more than 1000 trees (data not shown), except for the Macaronesian broadleaves (350 trees), in accordance with the rule of the thumb (Elith et al. 2008). Despite the low number of trees for the Macaronesian broadleaves, the deviance explained by the BRT for this forest type reached a maximum value (55\%). The minimum values for this statistic were for Productive plantations and Subalpine and oromediterranean conifers (35-36\%).

\section{Discussion}

This is the first study addressing shrub richness in woodlands at the Spanish national level. Among all the variables studied, our results reveal that climatic conditions (particularly 
rainfall variability) followed by soil features correlate best with shrub richness, explaining around $38 \%$ of the variance. Similarly, Corney et al. (2006) found that the field vegetation in temperate forests is primarily structured by geo-climatic factors. In contrast to our findings, Wang et al. (2017) reported that shrub richness in a dryland ecosystem of Northwest China is mainly limited by soil attributes rather than by climatic conditions. Jordan et al. (2020) found that shrub richness is associated with ecohydrological predictors such as slope, elevation, the number of days with dry lower soil layers or the number of days with wet upper soil layers, although these relationships were weak. This contradiction can be attributable to the influence of the spatial scale covered and the climatic heterogeneity existing in the area studied. At a large scale, the effect of climatic variables may predominate whereas the importance of other variables such as edaphic and topographical may become more significant at smaller spatial scales (Olthoff et al. 2016, 2018).

Several other studies have also highlighted the role of variation in rainfall as a determining factor in plant richness and floristic composition in rainforests (Oliveira-Filho and Fontes (2000) using the rainfall distribution ratio as the porportion between the mean precipitation of the dry and rainy seasons) and semi-deciduous forests (Kristiansen et al. (2011) using the coefficient of variation of monthly precipitation). The importance of including the variation in rainfall, however, becomes more apparent on analysing the interactions with Temperature and Rainfall, which reveal that shrub species mainly grow in coastal Mediterranean forests with low rainfall and high temperature. The high species richness occurring in sites with these harsh conditions may be attributable to the fact that hydric stress is more limiting to the trees than to the shrubs (Martín-Queller et al. 2011; Bateman et al. 2018). Adaptation to environmental heterogeneity and wildfires in the Mediterranean basin contributes to explaining why this region displays the highest species richness in comparison with other parts of the country (Cowling et al. 1996). Additionally, the relative mildness of past climates may have provided refugia for some species and new ones may have emerged (Postigo Mijarra et al. 2009; Verdú and Pausas 2013; Molina-Venegas et al. 2017).

Nitrogen was the soil variable most strongly correlated to shrub richness. In concordance with this finding, LópezMarcos et al. (2019) found a significant and strong association between the hemicryptophytes growing in the understory and soil fertility in mixed pine forests in Spain. Das Gupta and Pinno (2020) found that soil nutrients are linked to understory richness in boreal forests, but that the direction of the effect depends on the type of forest. Similarly, Wang et al. (2017) found that shrub species were negatively related to soil nutrients whereas Härdtle et al. (2003) argued that nutrient supply only has a weak influence on ground species richness in moist German forests. In contrast, our results indicate a non-linear (bell-shape relationship) between soil nitrogen and shrub richness, which suggests that shrub richness decreases beyond moderate nitrogen content values. The difference between our results for nitrogen content and those of previous studies may be explained by i) the wider ecological gradient at a large spatial considered in our study compared to the finer scales with a narrower ecological gradient of previous studies (see Olthoff et al. 2016) and ii) the statistical approach used in this study (boosted regression trees), which allowed the identification of non-linear relationships

Our findings suggest that the number of shrub species reaches a maximum at lower DBH values and decreases progressively as the DBH increases. At younger stages of tree development, trees and shrub display specific interactions of facilitation and competition (Gómez-Aparicio et al. 2004; Madrigal-González et al. 2014; Cruz-Alonso et al. 2020). However, when the tree stratum increases in size the shrubs do not interfere with mature trees (Vilà et al. 2007) but the amount of light reaching the lower strata drops and may hamper the development of the shrub layer (Barbier et al. 2008). In this regard, several studies have found that shrub richness is negatively related to tree cover (basal area and/or tree density) (Martín-Queller et al. 2011; Kepfer-Rojas et al. 2017; Moreno-Fernández et al. 2020). However, the contribution of basal area to explaining shrub richness at country scale was relatively minor and the role of tree density was residual. This result agrees with those of Gracia et al. (2007) and Cruz-Alonso et al. (2021) for temperate forests in the central Pyrenees and low land forests in Mediterranean areas, respectively. We hypothesized that the residual effect of basal area on shrub richness can be due to the structural heterogeneity of Mediterranean forests which ranges from openwoodlands or with low densities to temperate and high montane.

The climatic, soil, stand and topographic variables explained around $38 \%$ of the variance, while the remaining unexplained variance may be attributable to unmeasured variables. In this regard, management practices, forest conservation status, microbial diversity as well as disturbances such as wildfires are expected to affect the composition of the shrub stratum (Dias et al. 2016; Silva et al. 2019, 2020; Das Gupta and Pinno 2020).

In contrast to the findings reported by Härdtle et al. (2003), our results indicate that the importance of the groups of variables driving shrub richness does not differ markedly among forest types. The number of shrub species, however, differed among the different forest types. The mean shrub richness by forest type supports the notion that the Mediterranean region contains the greatest shrub richness. Single species forests of Evergreen broadleaves (e.g. Quercus ilex L., Quercus suber L., Ceratonia siliqua L., Olea europaea) and Mediterranean conifers (e.g. 
Pinus pinaster mesogeensis Ait., Pinus pinea L., Pinus halepensis Mill., Abies pinsapo Boiss., Juniperus spp) tend to have a higher number of shrub species than forests of Subalpine and oro-mediterranean conifers (e.g., Pinus sylvestris L., P. nigra or Abies alba) or Deciduous broadleaves (e.g., Castanea sativa Mill., Fagus sylvatica L., Betula spp., Quercus petraea (Matt.) Liebl., Quercus robur L.) (Moreno-Fernández et al. 2020). Despite the low tree density in Open woodlands (agrosilvicultural systems mainly dominated by $Q$. ilex and $Q$. suber), this forest type presented a low number of shrub species. However, land-use practices such as shrub clearing to promote pasture reduce the shrub cover and therefore species richness (Plieninger et al. 2004; López-Sánchez et al. 2016). As regards the low number of shrubs in Deciduous broadleaf forests, it is worth noting that these stands, such as those of $F$. sylvatica, are very closed, which hampers the establishment of the shrub cover (Barbier et al. 2008).

Macaronesia is considered to be one of the richest areas in Europe, containing many endemic endangered plant species (Romeiras et al. 2016; Patiño et al. 2016). However, our findings reveal that this region and the forest types found there (Macaronesian broadleaves and conifers) have the lowest shrub richness values of all the regions of the country. This may be because a lot of species belong to the tree stratum according to the NFI classification (e.g., Ilex canariensis Poir., Myrica faya Ait. or Persea indica (L.) Spreng) or to the herb stratum, or do not grow in forests (Arozena and Panareda 2013).

In this study, we used a single inventory, i.e., a static approach, which does not allow demographic changes to be detected. The results identify gaps in our knowledge that must be addressed in future studies, such as identifying changes in shrub species assemblages or the replacement of the tree layer by the shrub stratum as a consequence of more arid conditions.

Although NFIs provide the largest source of forest data at country level, they present certain limitations. As in most NFIs, the Spanish NFI only identifies a selection of shrub species (or taxa) according to a national list (Torras et al. 2009; Alberdi et al. 2010, 2018; Olthoff et al. 2021). Hence, it does not provide a complete inventory and several rare and not frequent species are not recorded, which influences total richness although it should not modify general tendencies. Finally, the fact that some specific information is gathered at genus level restricts more in-depth analyses to establish possible associations between overstory and understory species or the estimation of alpha, beta and gamma diversity. In this regard, future research should aim to infer the difference in shrub richness and diversity derived from the NFI and other data sources.

\section{Conclusions}

Our results highlight the importance of considering the spatial patterns of biotic and abiotic variables as well as the interaction between these variables along with non-linear relationships for the assessment of plant-species richness. Shrub richness in Spain is primarily driven by climatic and soil variables, both at country and forest-type scales. Of the four biogeographical regions, the Mediterranean region is that which contains the greatest diversity of shrub species growing in Spanish forests. Additionally, this region, as well as the transition zone between the Mediterranean and EuroSiberian regions, is prone to suffer the effects of climate change, reduction in rainfall and more frequent occurrence of extreme high-temperature events (Giorgi and Lionello 2008). Therefore, we acknowledge the importance of monitoring programs and specific studies undertaken in Mediterranean forest ecosystems. Moreover, future studies should address the impacts of global change on the shrub stratum in the Mediterranean region.

\section{Appendix 1 Maps of the mean predictors of shrub richness.}

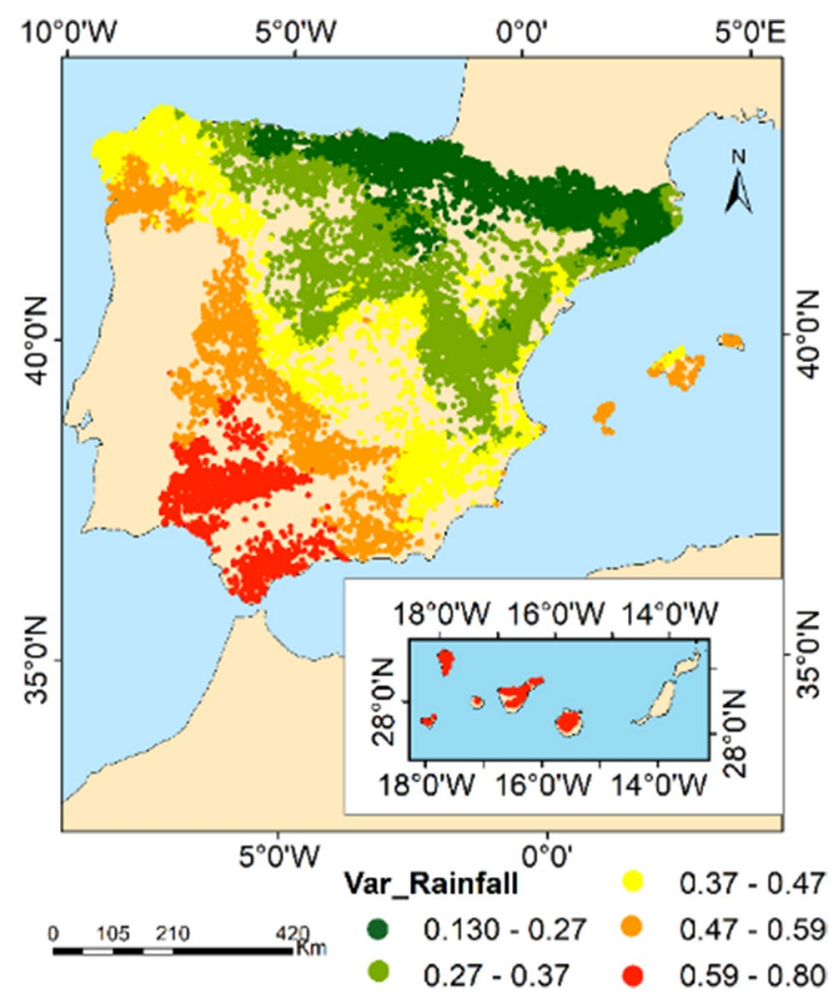

Fig. 5 Variability of rainfall 


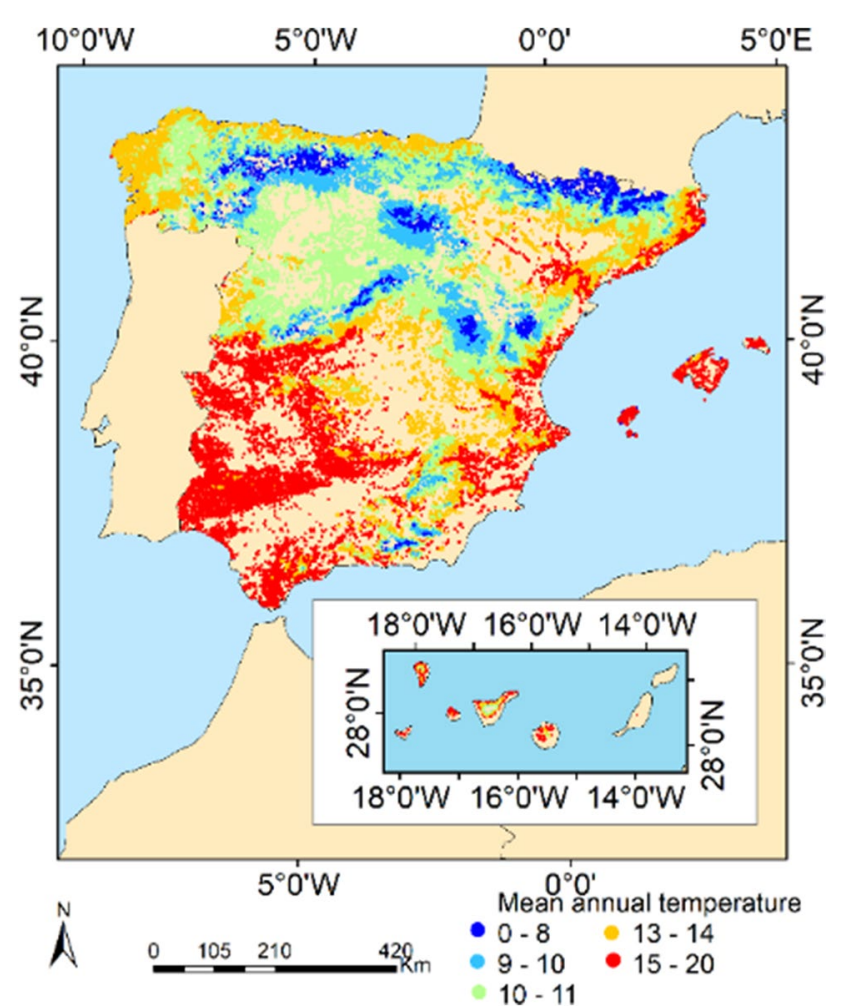

Fig. 6 Mean annual temperature $\left({ }^{\circ} \mathrm{C}\right)$

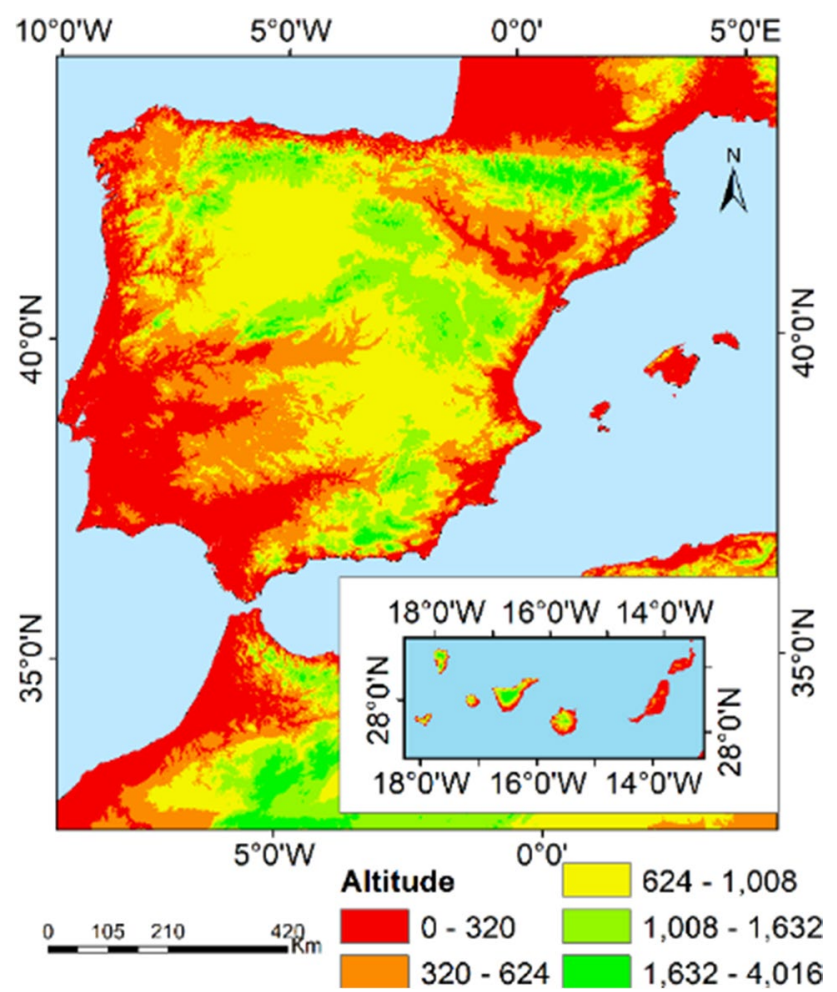

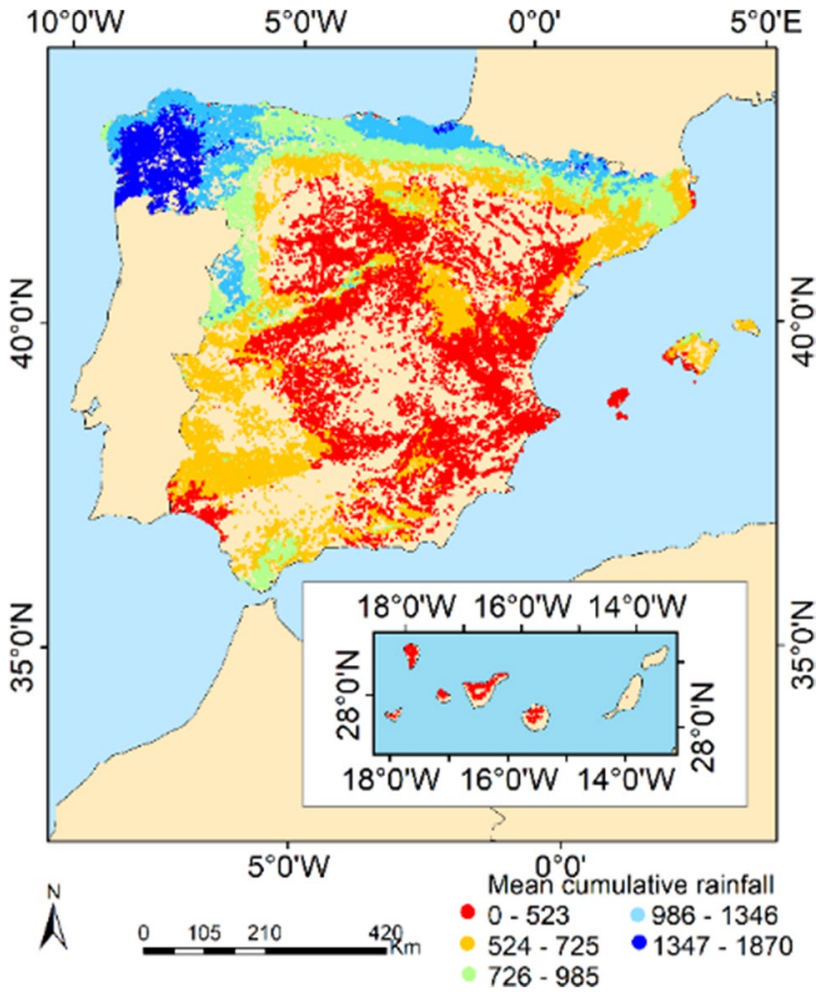

Fig. 8 Mean cumulative rainfall (mm)

Fig. 7 Altitude (m) 


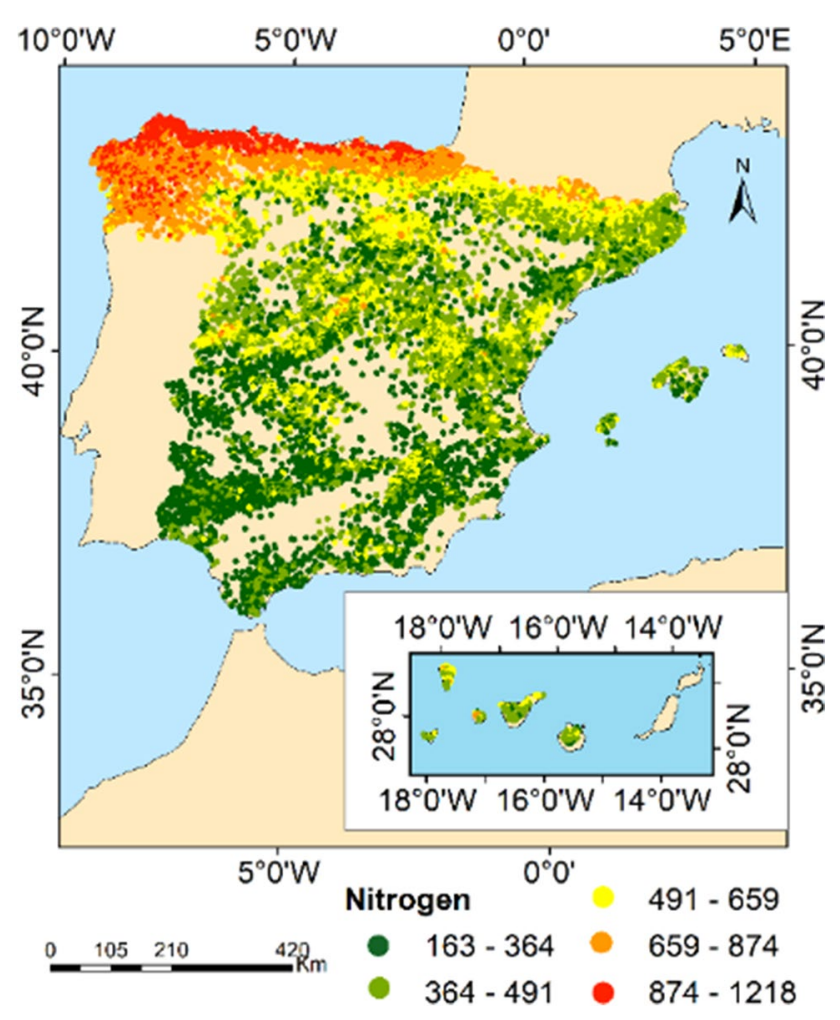

Fig. 9 Nitrogen $(\mathrm{cg} / \mathrm{kg})$

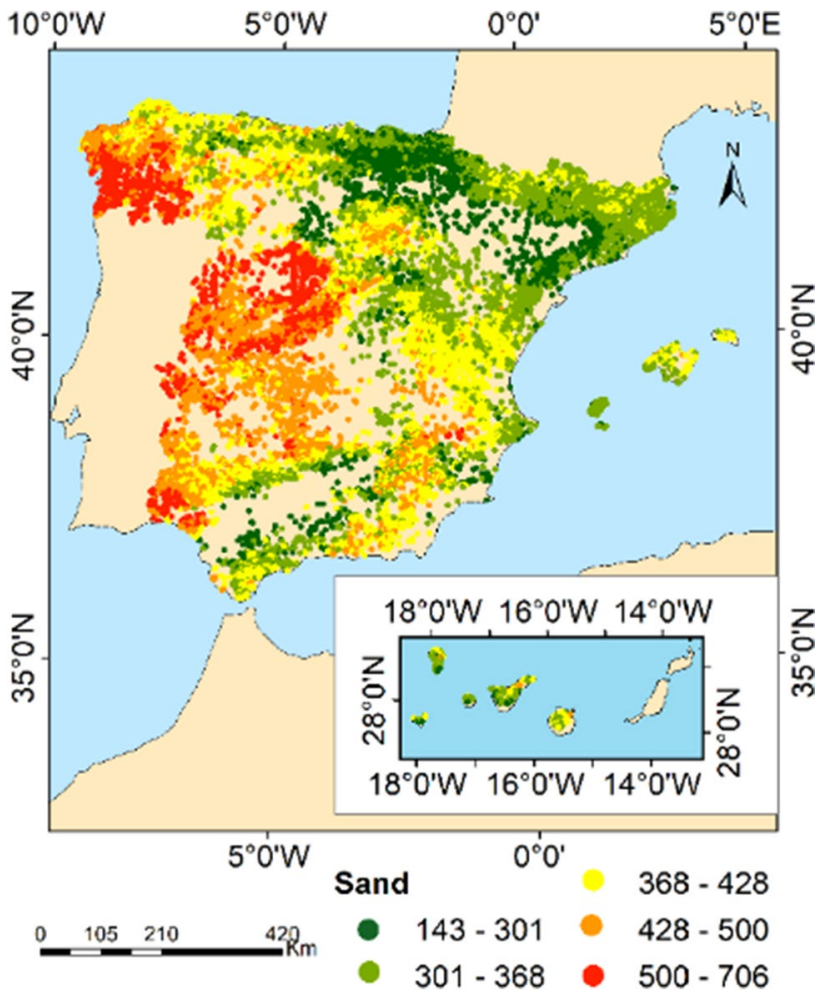

Fig. 10 Sand $(\mathrm{g} / \mathrm{kg})$ 


\section{Appendix 2}

Table 5 List of shrub species monitored in the Third Spanish National Forest Inventory.

Adenocarpus decorticans Boiss.

Adenocarpus gibbsianus Castrov. \& Talavera

Adenocarpus spp.

Adenocarpus telonensis (Loisel.) DC.

Ampelodesmos mauritanicus (Poir.) T. Durand \& Schinz

Anagyris foetida L.

Anagyris spp.

Anthyllis cytisoides L.

Arctostaphylos uva-ursi (L.) Spreng.

Artemisia canariensis (Besser) Less.

Artemisia reptans C.Sm.

Artemisia spp.

Artemisia barrelieri Besser

Artemisia campestris Ledeb., 1833

Asparagus spp.

Astragalus spp.

Atriplex spp.

Berberis vulgaris $\mathrm{L}$.

Bupleurum gibraltaricum Lam.

Bupleurum fruticescens Loefl. ex L.

Bupleurum fruticosum $\mathrm{L}$.

Bupleurum spinosum Gouan \& Ill.Observ.Bot.

Bupleurum spp.

Calicotome spinosa (L.) Link

Calicotome villosa (Poir.) Link

Calluna vulgaris (L.) Hull

Chamaecytisus proliferus (L.f.) Link

Chamaespartium tridentatum (L.) P.E.Gibbs

Cistus albidus L.

Cistus clusii Dunal

Cistus crispus L.

Cistus ladanifer $\mathrm{L}$.

Cistus laurifolius $\mathrm{L}$.

Cistus libanotis L.

Cistus monspeliensis L.

Cistus populifolius $\mathrm{L}$.

Cistus psilosepalus Sweet

Cistus salviifolius $\mathrm{L}$.

Cistus spp.

Cistus symphytifolius Lam.

Clematis flammula $\mathrm{L}$.

Clematis spp.

Clematis vitalba $\mathrm{L}$.

Colutea arborescens $\mathrm{L}$.

Corema album (L.) D.Don

Corema spp. 
Table 5 (continued)

Coriaria myrtifolia L.

Coronilla emerus $\mathrm{Sm}$.

Coronilla glauca L.

Coronilla juncea $\mathrm{L}$.

Coronilla minima $\mathrm{L}$.

Coronilla spp.

Cotoneaster spp.

Cytisophyllum sessilifolium (L.) O.Lang

Cytisus baeticus (Webb) Steud.

Cytisus grandiflorus DC.

Cytisus malacitanus Boiss.

Cytisus scoparius (L.) Link

Cytisus spp.

Cytisus striatus (Hill) Rothm.

Cytisus tribracteolatus Webb

Cytisus villosus Pourr.

Daboecia cantabrica (Huds.) C.Koch

Daphne gnidium L.

Daphne laureola $\mathrm{L}$.

Daphne mezereum L.

Daphne L.

Dittrichia viscosa (L.) Greuter

Dorycnium hirsutum (L.) Ser.

Dorycnium pentaphyllum Scop.

Dorycnium spp.

Echinospartum boissieri (Spach) Rothm.

Echinospartum spp.

Echium spp.

Ephedra fragilis Desf.

Ephedra spp.

Erica arborea L.

Erica australis L.

Erica ciliaris L.

Erica cinerea L.

Erica erigena R.Ross

Erica multiflora $\mathrm{L}$.

Erica scoparia L.

Erica spp.

Erica umbellata L.

Erica vagans $\mathrm{L}$.

Erinacea anthyllis Link

Erinacea spp.

Euphorbia aphylla Brouss. ex Willd.

Euphorbia canariensis L.

Euphorbia handiensis Burchard

Euphorbia spp. 
Table 5 (continued)

Genista baetica Spach

Genista balansae (Boiss.) Rouy

Genista cinerea (Vill.) DC.

Genista hirsuta Vahl

Genista linifolia L.

Genista monspessulana (L.) L.A.S.Johnson

Genista patens DC.

Genista scorpius (L.) DC.

Genista spp.

Genista triacanthos Brot.

Genista tridens (Cav.) DC.

Genista tridentata L.

Genista triflora (Lam.) Rouy

Genista umbellata (L'Her.) Poir.

Genista versicolor Boiss.

Genistella spp.

Globularia alypum L.

Halimium atriplicifolium (Lam.) Spach

Halimium commutatum $\mathrm{Pau}$

Halimium halimifolium (L.) Willk.

Halimium lasianthum (Lam.) Spach

Halimium spp.

Hedera helix $\mathrm{L}$.

Helianthemum Mill.

Helichrysum stoechas (L.) Moench

Helichrysum italicum (Roth) G.Don

Hypericum canariense Brouss.

Jasminum fruticans L.

Juniperus sabina L.

Kleinia neriifolia Haw.

Launaea arborescens (Batt.) Murb.

Lavandula lanata Boiss.

Lavandula latifolia Medik.

Lavandula spp.

Lavandula stoechas $\mathrm{L}$.

Ligustrum vulgare $\mathrm{L}$.

Lithodora spp.

Lonicera etrusca Santi

Lonicera implexa Sol.

Lonicera periclymenum $\mathrm{L}$.

Lonicera pyrenaica $\mathrm{L}$.

Lonicera spp.

Lonicera xylosteum $\mathrm{L}$.

Maytenus canariensis (Loes.) Kunkel \& Sunding

Maytenus senegalensis (Lam.) Exell

Medicago arborea $\mathrm{L}$. 
Table 5 (continued)

Nerium oleander L.

Ononis spp.

Ononis tridentata $\mathrm{L}$.

Osyris alba L.

Osyris quadripartita Salzm. ex Decne.

Osyris spp.

Papilionaceae - High size species

Papilionaceae - Small size species

Paliurus spina-christi Mill.

Periploca laevigata Aiton

Phillyrea angustifolia L.

Phlomis lychnitis L.

Phlomis purpurea $\mathrm{L}$.

Phlomis spp.

Pistacia lentiscus L.

Prunus mahaleb L.

Prunus ramburii Boiss.

Quercus coccifera $\mathrm{L}$.

Quercus fruticosa Brot.

Retama monosperma (L.) Boiss.

Retama sphaerocarpa (L.) Boiss.

Retama spp.

Rhamnus alaternus $\mathrm{L}$.

Rhamnus alpina $\mathrm{L}$.

Rhamnus lycioides $\mathrm{L}$.

Rhamnus myrtifolia Willk.

Rhamnus oleoides L.

Rhamnus saxatilis Jacq.

Rhamnus spp.

Rhododendron ponticum $\mathrm{L}$.

Rhododendron spp.

Ribes alpinum L.

Ribes rubrum $\mathrm{L}$.

Ribes spp.

Rosa spp.

Rosmarinus tomentosus Hub.-Mor. \& Maire

Rubus caesius L.

Rubus idaeus L.

Rubus spp.

Rubus ulmifolius Schott

Rumex lunaria L.

Ruscus aculeatus L.

Ruscus hypophyllum L.

Salsola spp.

Salvia rosmarinus Schleid.

Sambucus palmensis Link 
Table 5 (continued)

Santolina rosmarinifolia $\mathrm{L}$.

Santolina spp.

Sarothamnus scoparius (L.) Wimm. ex W.D.J.Koch

Sarothamnus vulgaris Wimm.

Securinega tinctoria (L.) Rothm.

Sideritis spp.

Smilax aspera $\mathrm{L}$.

Spartium junceum L.

Spartium spp.

Spiraea spp.

Stauracanthus boivinii (Webb) Samp.

Teline spp.

Teucrium fruticans $\mathrm{L}$.

Teucrium spp.

Thymelaea spp.

Thymus albicans Hoffmanns. \& Link

Thymus baeticus Boiss. ex Lacaita

Thymus granatensis Boiss.

Thymus mastichina (L.) L.

Thymus spp.

Thymus zygis $\mathrm{L}$.

Ulex baeticus Boiss.

Ulex canescens Lange

Ulex eriocladus $\mathrm{C}$.Vicioso

Ulex minor Roth

Ulex parviflorus Pourr.

Ulex spp.

Vaccinium myrtillus L.

Vella spinosa Boiss.

Vella spp.

Viburnum rigidum Vent.

Viburnum spp.

Viburnum tinus $\mathrm{L}$.

Vitis vinifera $\mathrm{L}$.

Withania frutescens (L.) Pauquy

Ziziphus lotus Aitch. 


\section{Appendix 3}

Table 6 Interaction size for the variables included in the boosted regression trees for the data as a whole. Large values of the interaction size indicate strong interactions. SM3 Interaction size for the variables included in the boosted regression trees for the data as a whole. Large values of the interaction size indicate strong interactions.

\begin{tabular}{ll}
\hline Interaction & Interaction size \\
\hline Var_Rainfall x Temperature & 11.16 \\
Var_Rainfall x Rainfall & 7.28 \\
Sand x Rainfall & 3.84 \\
Var_Rainfall x Altitude & 3.34 \\
Sand x Var_Rainfall & 3.05 \\
Sand x Temperature & 2.78 \\
Nitrogen x Altitude & 1.59 \\
Silt x Rainfall & 1.57 \\
Temperature x Rainfall & 1.52 \\
CEC x Rainfall & 1.34 \\
Var_Rainfall x Slope & 1.16 \\
Var_Rainfall x pH & 1.14 \\
Silt x Var_Rainfall & 1.01 \\
Var_Temp x Temperature & 0.98 \\
Sand x Altitude & 0.88 \\
Bulk x Var_Rainfall & 0.85 \\
Nitrogen x DBH & 0.84 \\
Nitrogen x BA & 0.76 \\
\hline
\end{tabular}

Rainfall = mean cumulative rainfall; Temp = mean annual temperature; Var_temp and Var_Rainfall = temperature and rainfall variability as the ratio of the standard deviation of monthly values and the mean, respectively; $\mathrm{DBH}=$ mean plot $\mathrm{dbh} ; \mathrm{N}=$ number of trees per ha; $\mathrm{CEC}=$ cation exchange capacity at ph 7

Acknowledgements We thank Adam Collins for revising and editing the English and Laura Hernández for her comments on the first draft. We also thank Paula Gil for her description of NFI shrub selection criteria. We recognize the comments made by the reviewers and the editors of Annals of Forest Science.

Code availability The custom code and/or software application generated during and/or analysed during the current study are available from the corresponding author on reasonable request.

Author contribution DM-F: data analysis and writing the first draft. IC \& IA: reviewing and editing the manuscript; support with shrub NFI dataset.

Funding Open Access funding provided thanks to the CRUE-CSIC agreement with Springer Nature. D M-F is supported by a Juan de la Cierva Formación post-doctoral fellowship (FJC2018-037870-I) from the Spanish Ministry of Science and Innovation.

Data availability The datasets generated and/or analyzed during the current study are available in the Spanish National Forest Inventory repository, https://www.miteco.gob.es/es/biodiversidad/servicios/ banco-datos-naturaleza/informacion-disponible/ifn3_base_datos_1_ 25.aspx

and https://www.miteco.gob.es/es/biodiversidad/servicios/bancodatos-naturaleza/informacion-disponible/ifn3_base_datos_26_50.aspx

\section{Declarations}

Ethics approval Not applicable

Consent to participate Not applicable

Consent for publication All authors gave their informed consent to this publication and its content.

Competing interests The authors declare no competing interests.

Open Access This article is licensed under a Creative Commons Attribution 4.0 International License, which permits use, sharing, adaptation, distribution and reproduction in any medium or format, as long as you give appropriate credit to the original author(s) and the source, provide a link to the Creative Commons licence, and indicate if changes were made. The images or other third party material in this article are included in the article's Creative Commons licence, unless indicated otherwise in a credit line to the material. If material is not included in the article's Creative Commons licence and your intended use is not permitted by statutory regulation or exceeds the permitted use, you will need to obtain permission directly from the copyright holder. To view a copy of this licence, visit http://creativecommons.org/licenses/by/4.0/.

\section{References}

Alberdi I, Condés S, Martínez-Millán J (2010) Review of monitoring and assessing ground vegetation biodiversity in national forest inventories. Environ Monit Assess 164:649-676. https://doi.org/ 10.1007/S10661-009-0919-4

Alberdi I, Condés S, McRoberts RE, Winter S (2018) Mean species cover: a harmonized indicator of shrub cover for forest inventories. Eur J For Res 137:265-278. https://doi.org/10.1007/ s10342-018-1110-7

Alberdi I, Hernández L, Condés S, Cañellas I (2016) Spain. In: Vidal C, I A, Hernández L, Redmond J (eds) National Forest Inventories. Assessment of wood availability and use. Springer, pp 749-769

Alday JG, Zaldívar P, Torroba-Balmori P et al (2016) Natural forest expansion on reclaimed coal mines in Northern Spain: the role of native shrubs as suitable microsites. Environ Sci Pollut Res Int 23:13606-13616. https://doi.org/10.1007/S11356-015-5681-2

Arozena ME, Panareda JM (2013) Forest transition and biogeographic meaning of the current laurel forest landscape in Canary Islands, Spain. Phys Geogr 34:211-235. https://doi.org/10.1080/02723 646.2013.817181

Barbier S, Gosselin F, Balandier P (2008) Influence of tree species on understory vegetation diversity and mechanisms involved-A critical review for temperate and boreal forests. For Ecol Manag 254:1-15. https://doi.org/10.1016/j.foreco.2007.09.038

Bateman A, Lewandrowski W, Stevens JC, Muñoz-Rojas M (2018) Ecophysiological Indicators to Assess Drought Responses of Arid Zone Native Seedlings in Reconstructed Soils. L Degrad Dev 29:984-993. https://doi.org/10.1002/LDR.2660 
Bhatta KP, Grytnes JA, Vetaas OR (2018) Scale sensitivity of the relationship between alpha and gamma diversity along an alpine elevation gradient in central Nepal. J Biogeogr 45:804-814. https:// doi.org/10.1111/jbi.13188

Cantarello E, Newton AC (2008) Identifying cost-effective indicators to assess the conservation status of forested habitats in Natura 2000 sites. For Ecol Manag 256:815-826. https://doi.org/10.1016/J. FORECO.2008.05.031

Chandler M, See L, Copas K et al (2017) Contribution of citizen science towards international biodiversity monitoring. Biol Conserv 213:280-294. https://doi.org/10.1016/j.biocon.2016.09.004

Corney PM, Duc MGL, Smart SM et al (2006) Relationships between the species composition of forest field-layer vegetation and environmental drivers, assessed using a national scale survey. J Ecol 94:383-401. https://doi.org/10.1111/J.1365-2745.2006.01094.X

Cowling RM, Rundel PW, Lamont BB et al (1996) Plant diversity in mediterranean-climate regions. Trends Ecol Evol 11:362-366. https://doi.org/10.1016/0169-5347(96)10044-6

Cruz-Alonso V, Espelta JM, Pino J (2021) Woody species richness and turnover in expanding Mediterranean forests : a story of landscape legacies influenced by climatic aridity. Landsc Ecol 0123456789: https://doi.org/10.1007/s10980-021-01249-z

Cruz-Alonso V, Villar-Salvador P, Ruiz-Benito P et al (2020) Longterm dynamics of shrub facilitation shape the mixing of evergreen and deciduous oaks in Mediterranean abandoned fields. $\mathrm{J}$ Ecol 108:1125-1137. https://doi.org/10.1111/1365-2745.13309

Das Gupta S, Pinno BD (2020) Drivers of understory species richness in reconstructed boreal ecosystems: a structural equation modeling analysis. Sci Rep 10:11555. https://doi.org/10.1038/ s41598-020-68353-z

De'ath G (2007) Boosted Trees for Ecological Modeling and Prediction. Ecology 88:243-251. https://doi.org/10.1890/00129658(2007)88[243:BTFEMA]2.0.CO;2

Dedman S, Officer R, Clarke M et al (2017) Gbm.auto: A software tool to simplify spatial modelling and Marine Protected Area planning. PLoS One 12:1-16. https://doi.org/10.1371/journal. pone.0188955

Di Pasquale G, Saracino A, Bosso L et al (2020) Coastal Pine-Oak Glacial Refugia in the Mediterranean Basin: A Biogeographic Approach Based on Charcoal Analysis and Spatial Modelling. Forests 11:673. https://doi.org/10.3390/f11060673

Dias FS, Miller DL, Marques TA et al (2016) Conservation zones promote oak regeneration and shrub diversity in certified Mediterranean oak woodlands. Biol Conserv 195:226-234. https://doi. org/10.1016/j.biocon.2016.01.009

Duan M, House J, Chang SX (2019) Understory plant communities vary with tree productivity in two reclaimed boreal upland forest types in Canada. For Ecol Manag 453:117577. https://doi.org/10. 1016/j.foreco.2019.117577

Elith J, Leathwick JR, Hastie T (2008) A working guide to boosted regression trees. J Anim Ecol 77:802-813. https://doi.org/10. $1111 /$ j.1365-2656.2008.01390.x

Fick SE, Hijmans RJ (2017) WorldClim 2: new 1-km spatial resolution climate surfaces for global land areas. Int J Climatol 37:43024315. https://doi.org/10.1002/joc.5086

Focardi S, Tinelli A (2005) Herbivory in a Mediterranean forest: Browsing impact and plant compensation. Acta Oecol 28:239_ 247. https://doi.org/10.1016/j.actao.2005.05.010

Friedman J (2001) Greedy function approximation: a gradient boosting machine. Ann Stat 29:1189-1232

Gastón A, Blázquez-Cabrera S, Ciudad C et al (2019) The role of forest canopy cover in habitat selection: insights from the
Iberian lynx. Eur J Wildl Res 65:10344. https://doi.org/10.1007/ s10344-019-1266-6

Giorgi F, Lionello P (2008) Climate change projections for the Mediterranean region. Glob Planet Chang 63:90-104. https://doi.org/ 10.1016/j.gloplacha.2007.09.005

Gómez-Aparicio L, Zamora R, Gómez JM et al (2004) Applying plant facilitation to forest restoration In Mediterranean ecosystems: A meta-analysis of the shrubs as nurse plants. Ecol Appl 14:1118-1138. https://doi.org/10.1890/03-5084

González-González BD, Sixto H, Alberdi I et al (2017) Estimation of shrub biomass availability along two geographical transects in the Iberian Peninsula for energy purposes. Biomass Bioenergy 105:211-218. https://doi.org/10.1016/j.biombioe.2017.07.011

Gracia M, Montané F, Piqué J, Retana J (2007) Overstory structure and topographic gradients determining diversity and abundance of understory shrub species in temperate forests in central Pyrenees (NE Spain). For Ecol Manag 242:391-397. https://doi. org/10.1016/j.foreco.2007.01.056

Habel JC, Rasche L, Schneider UA et al (2019) Final countdown for biodiversity hotspots. Conserv Lett 12:e12668. https://doi.org/10. $1111 /$ conl.12668

Härdtle W, Von Oheimb G, Westphal C (2003) The effects of light and soil conditions on the species richness of the ground vegetation of deciduous forests in northern Germany (Schleswig-Holstein). For Ecol Manag 182:327-338. https://doi.org/10.1016/S03781127(03)00091-4

Hewitt GM (2011) Mediterranean Peninsulas: The Evolution of Hotspots. In: Zachos F, Habel JC (eds) Biodiversity Hotspots. Springer, Berlin Heidelberg, Berlin, Heidelberg, pp 123-147

Jensen AM, Götmark F, Löf M (2012) Shrubs protect oak seedlings against ungulate browsing in temperate broadleaved forests of conservation interest: A field experiment. For Ecol Manag 266:187-193. https://doi.org/10.1016/j.foreco.2011.11.022

Jordan SE, Palmquist KA, Bradford JB, Lauenroth WK (2020) Soil water availability shapes species richness in mid-latitude shrub steppe plant communities. J Veg Sci 31:646-657. https://doi.org/ $10.1111 /$ jvs. 12874

Kepfer-Rojas S, Damgaard C, Riis-Nielsen T, Schmidt IK (2017) Interactive effects of land-use history, tree encroachment and distance to edge on species richness in an unmanaged heathland. Appl Veg Sci 20:74-83. https://doi.org/10.1111/avsc. 12270

Kristiansen T, Svenning JC, Pedersen D et al (2011) Local and regional palm (Arecaceae) species richness patterns and their cross-scale determinants in the western Amazon. J Ecol 99:1001-1015. https://doi.org/10.1111/j.1365-2745.2011.01834.x

Lasanta T, Khorchani M, Pérez-Cabello F et al (2018) Clearing shrubland and extensive livestock farming: Active prevention to control wildfires in the Mediterranean mountains. J Environ Manag 227:256-266. https://doi.org/10.1016/j.jenvman.2018.08.104

Liu C-C, Liu Y-G, Guo K et al (2011) Comparative ecophysiological responses to drought of two shrub and four tree species from karst habitats of southwestern China. Trees 25:537-549. https://doi.org/ 10.1007/s00468-010-0533-7

López-Marcos D, Turrión MB, Bravo F, Martínez-Ruiz C (2019) Understory response to overstory and soil gradients in mixed versus monospecific Mediterranean pine forests. Eur J For Res 138:939-955. https://doi.org/10.1007/s10342-019-01215-0

López-Marcos D, Turrión MB, Martínez-Ruiz C (2020) Linking soil variability with plant community composition along a mine-slope topographic gradient: Implications for restoration. Ambio 49:337. https://doi.org/10.1007/S13280-019-01193-Y

López-Sánchez A, Perea R, Dirzo R, Roig S (2016) Livestock vs. wild ungulate management in the conservation of Mediterranean 
dehesas: Implications for oak regeneration. For Ecol Manag 362:99-106. https://doi.org/10.1016/j.foreco.2015.12.002

Madrigal-González J, García-Rodríguez JA, Zavala MA (2014) Shrub encroachment shifts the bioclimatic limit between marcescent and sclerophyllous oaks along an elevation gradient in west-central Spain. J Veg Sci 25:514-524. https://doi.org/10.1111/jvs.12088

Maestre FT, Bowker MA, Puche MD et al (2009) Shrub encroachment can reverse desertification in semi-arid Mediterranean grasslands. Ecol Lett 12:930-941. https://doi.org/10.1111/j.1461-0248.2009. 01352.x

Martín-Queller E, Gil-Tena A, Saura S (2011) Species richness of woody plants in the landscapes of Central Spain: The role of management disturbances, environment and non-stationarity. J Veg Sci 22:238-250. https://doi.org/10.1111/j.1654-1103.2010.01242.x

Miina J, Pukkala T, Kurttila M (2016) Optimal multi-product management of stands producing timber and wild berries. Eur J For Res 135:781-794. https://doi.org/10.1007/s10342-016-0972-9

MITECO (2013) Ministerio para la Transición ecológica y el Reto demográfico. The Spanish National Forest Map. https://www. miteco.gob.es/es/biodiversidad/servicios/banco-datos-naturaleza/ informacion-disponible/mfe50_descargas_ccaa.aspx

Mohammad AG, Adam MA (2010) The impact of vegetative cover type on runoff and soil erosion under different land uses. Catena 81:97-103. https://doi.org/10.1016/j.catena.2010.01.008

Molina-Venegas R, Aparicio A, Lavergne S, Arroyo J (2017) Climatic and topographical correlates of plant palaeo- and neoendemism in a Mediterranean biodiversity hotspot. Ann Bot 119:229-238. https://doi.org/10.1093/aob/mcw093

Moreno-Fernández D, Cañellas I, Rubio-Cuadrado Á, Alberdi I (2020) National scale variability in forest stand variables among regions of provenances in Spain. Ann For Sci 77:44. https://doi.org/10. 1007/s13595-020-00943-3

Moreno-Fernández D, Ledo A, Martín-Benito D et al (2019) Negative synergistic effects of land-use legacies and climate drive widespread oak decline in evergreen Mediterranean open woodlands. For Ecol Manag 432:884-894. https://doi.org/10.1016/j.foreco. 2018.10.023

Myers N, Mittermeier RA, Mittermeier CG et al (2000) Biodiversity hotspots for conservation priorities. Nature 403:853-858. https:// doi.org/10.1038/35002501

Oliveira-Filho AT, Fontes MAL (2000) Patterns of floristic differentiation among atlantic forests in southeastern Brazil and the influence of climate. Biotropica 32:793-810. https://doi.org/10.1111/j.17447429.2000.tb00619.x

Olthoff A, Martínez-Ruiz C, Alday JG (2016) Distribution patterns of forest species along an Atlantic-Mediterranean environmental gradient: An approach from forest inventory data. Forestry 89:46-54. https://doi.org/10.1093/forestry/cpv031

Olthoff AE, Gómez C, Alday JG, Martínez-Ruiz C (2018) Mapping forest vegetation patterns in an Atlantic-Mediterranean transitional area by integration of ordination and geostatistical techniques. J Plant Ecol 11:114-122. https://doi.org/10.1093/JPE/RTW112

Olthoff AE, Martínez-Ruiz C, Alday JG (2021) Niche Characterization of Shrub Functional Groups along an Atlantic-Mediterranean Gradient. For 2021, Vol 12, Page 982 12:982. https://doi.org/10. 3390/F12080982

Pasalodos-Tato M, Ruiz-Peinado R, del Río M (2015) Montero G (2015) Shrub biomass accumulation and growth rate models to quantify carbon stocks and fluxes for the Mediterranean region. Eur J For Res 1343(134):537-553. https://doi.org/10.1007/ S10342-015-0870-6

Patiño J, Mateo RG, Zanatta F et al (2016) Climate threat on the Macaronesian endemic bryophyte flora. Sci Rep 6:1-12. https://doi.org/ 10.1038/srep29156
Pérez-Ramos IM, Zavala MA, Marañón T et al (2008) Dynamics of understorey herbaceous plant diversity following shrub clearing of cork oak forests: A five-year study. For Ecol Manag 255:32423253. https://doi.org/10.1016/j.foreco.2008.01.069

Plieninger T, Pulido FJ, Schaich H (2004) Effects of land-use and landscape structure on holm oak recruitment and regeneration at farm level in Quercus ilex L. dehesas. J Arid Environ 57:345-364. https://doi.org/10.1016/S0140-1963(03)00103-4

Poggio L, De Sousa LM, Batjes NH et al (2021) SoilGrids 2.0: Producing soil information for the globe with quantified spatial uncertainty. SOIL 7:217-240. https://doi.org/10.5194/ SOIL-7-217-2021

Postigo Mijarra JM, Barrón E, Gómez Manzaneque F, Morla C (2009) Floristic changes in the Iberian Peninsula and Balearic Islands (south-west Europe) during the Cenozoic. J Biogeogr 36:20252043. https://doi.org/10.1111/j.1365-2699.2009.02142.x

R Core Team (2021) R: A language and environment for statistical computing

Rodríguez A, Kouki J (2015) Emulating natural disturbance in forest management enhances pollination services for dominant Vaccinium shrubs in boreal pine-dominated forests. For Ecol Manag 350:1-12. https://doi.org/10.1016/j.foreco.2015.04.029

Roekaerts M (2002) The Biogeographical Regions Map of Europe: Basic principles of its creation and overview of its development. European Environment Agency

Romeiras MM, Catarino S, Gomes I et al (2016) IUCN Red List assessment of the Cape Verde endemic flora: towards a global strategy for plant conservation in Macaronesia. Bot J Linn Soc 180:413425. https://doi.org/10.1111/boj.12370

Schmidt JP, Drake JM (2011) Why are some plant genera more invasive than others? PLoS One 6:e18654. https://doi.org/10.1371/journ al.pone. 0018654

Silva V, Catry FX, Fernandes PM et al (2019) Effects of grazing on plant composition, conservation status and ecosystem services of Natura 2000 shrub-grassland habitat types. Biodivers Conserv 28:1205-1224. https://doi.org/10.1007/s10531-019-01718-7

Silva V, Catry FX, Fernandes PM et al (2020) Trade-offs between fire hazard reduction and conservation in a Natura 2000 shrub-grassland mosaic. Appl Veg Sci 23:39-52. https://doi.org/10.1111/ avsc. 12463

Smit C, den Ouden J, Diaz M, Díaz M (2008) Facilitation of Quercus ilex recruitment by shrubs in Mediterranean open woodlands. J Veg Sci 19:193-200. https://doi.org/10.3170/2007-8-18352

Soykan CU, Eguchi T, Kohin S, Dewar H (2014) Prediction of fishing effort distributions using boosted regression trees. Ecol Appl 24:71-83. https://doi.org/10.1890/12-0826.1

Torras O, Gil-Tena A, Saura S (2008) Effects of silvicultural treatments on forest biodiversity indicators in the Mediterranean. For Ecol Manag 255:3322-3330. https://doi.org/10.1016/j.foreco.2008.02. 013

Torras O, Martín-Queller E, Saura S (2009) Relating landscape structure, environment and management to biodiversity indicators estimated from forest inventory data in Catalonia (NE Spain). Investig Agrar Sist Recur For 18:322-337. https://doi.org/10. 5424/fs/2009183-01072

Torroba-Balmori P, Zaldívar P, Alday JG et al (2015) Recovering Quercus species on reclaimed coal wastes using native shrubs as restoration nurse plants. Ecol Eng 77:146-153. https://doi.org/10. 1016/j.ecoleng.2015.01.024

Verdú M, Pausas JG (2013) Syndrome-driven diversification in a mediterranean ecosystem. Evolution (N Y) 67:1756-1766. https://doi. org/10.1111/evo.12049

Vicente-Serrano SM, Martín-Hernández N, Camarero JJ et al (2020) Linking tree-ring growth and satellite-derived gross primary 
growth in multiple forest biomes. Temporal-scale matters Ecol Indic 108:105753. https://doi.org/10.1016/j.ecolind.2019.105753

Vilà M, Vayreda J, Comas L et al (2007) Species richness and wood production: A positive association in Mediterranean forests. Ecol Lett 10:241-250. https://doi.org/10.1111/j.1461-0248.2007. 01016.x

Wang J, Long T, Zhong Y et al (2017) Disentangling the influence of climate, soil and belowground microbes on local species richness in a dryland ecosystem of Northwest China. Sci Rep 7:1-11. https://doi.org/10.1038/s41598-017-17860-7
Zilliox C, Gosselin F (2014) Tree species diversity and abundance as indicators of understory diversity in French mountain forests: Variations of the relationship in geographical and ecological space. For Ecol Manag 321:105-116. https://doi.org/10.1016/j. foreco.2013.07.049

Publisher's note Springer Nature remains neutral with regard to jurisdictional claims in published maps and institutional affiliations. 